Case Report

\title{
Hepatitis $E$ virus infection results in acute graft failure after liver transplantation: a case report
}

\author{
Xiangyan Liu, Tian Shen, Zhuoyi Wang, Li Zhuang, Wei Zhang, Jun Yu, Jian Wu, Shusen Zheng \\ Key Lab of Combined Multi-Organ Transplantation, Ministry of Public Health, Division of Hepatobiliary and \\ Pancreatic Surgery, Department of Surgery, First Affiliated Hospital, Zhejiang University School of Medicine, \\ Hangzhou, Zhejiang, China
}

\begin{abstract}
Hepatitis E virus (HEV) infection in most individuals is known as a self-limiting, acute, icteric hepatitis, but evidence shows HEV is responsible for choric hepatitis and rapid progressed liver cirrhosis in immuno-compromised patients. We present the case of a patient whose diagnosis of acute graft failure was due to a HEV infection 7 years after his first liver transplantation because of Wilson's disease. The process showed severe jaundice with fatigue, poor appetite and continually rising serum aminopherase. The blood serum was found positive for the anti-HEV IgG antibody but negative for anti-HEV IgM or other infections. Cholangiole cholestasis was detected in graft biopsy. Triple hepato-protective drugs (Transmetil, Polyene Phosphatidylcholine, and Compound Ammonium Glycyrrhetate S) alongside five times Artificial Liver Support System (ALSS) did not improve the patient's condition, but the total bilirubin level rose to more than 900umol/L. So re-transplantation was performed. Blood testing shows normal liver enzymes and bilirubin with persisting anti-HEV IgG antibody positive at the 3-month follow-up.
\end{abstract}

Key words: hepatitis E virus; graft failure; re-transplantation

J Infect Dev Ctries 2014; 8(2):245-248. doi:10.3855/jidc.3638

(Received 08 April 2013 - Accepted 05 May 2013)

Copyright $@ 2014$ Liu et al. This is an open-access article distributed under the Creative Commons Attribution License, which permits unrestricted use, distribution, and reproduction in any medium, provided the original work is properly cited.

\section{Introduction}

Hepatitis $\mathrm{E}$ virus infection is known as one of the most common reported hepatitis viruses in developing countries, and was also described several times in solid organ transplant recipients both adults and children, and other immuno-compromised diseases $[1,4]$. It causes chronic hepatitis and cirrhosis, associated with chronic liver failure $[5,6]$. But no acute liver failure has been reported yet in liver transplant recipients. So we present this case of hepatitis E virus infection that rapidly led to liver failure in a liver transplant recipient, in which ordinary medicine therapy and Artificial Liver Support made no difference. So the patient had to receive a retransplantation operation.

\section{Case Report}

In October 2012, a 23-year-old college student was referred to our department, First Affiliated Hospital of Zhejiang University, in Hangzhou, South China. He complained of fever, fatigue, bad appetite and darkcolored urine starting 3 days before admission. He firstly underwent liver transplantation because of Wilson's disease at age 16 , and took tacrolimus $0.5 \mathrm{mg}$ q12h, making normal serum aminopherase and bilirubin in the previous 7 years.

Laboratory data showed elevated alanine aminotransferase (ALT) and aspartate aminotranferase (AST), as well as the total bilirubin level and Prothrombin Time (see Table 1). Magnetic Resonance Cholangiopancreatography (MRCP) showed no obvious bile ducts stricture or obstruction. Anti-HEV IgG antibody was observed as weakly-positive, twice, during the second week after the beginning of the clinical manifestations, while other hepatitis viruses, like $\mathrm{HAV}, \mathrm{HBV}, \mathrm{HCV}$, as well as $\mathrm{CMV}$, were negative. Therefore based on the symptoms below, the increasing of ALT and TBIL level, especially the absence of the anti-HEV IgG antibody, he was diagnosed with an acute hepatitis $\mathrm{E}$ virus infection. Thereby a liver biopsy was performed and cholangiole cholestasis was observed, which further confirmed the diagnosis (Figure 1). 
Figure 1. Pathology shows cholangiole cholestasis in the liver

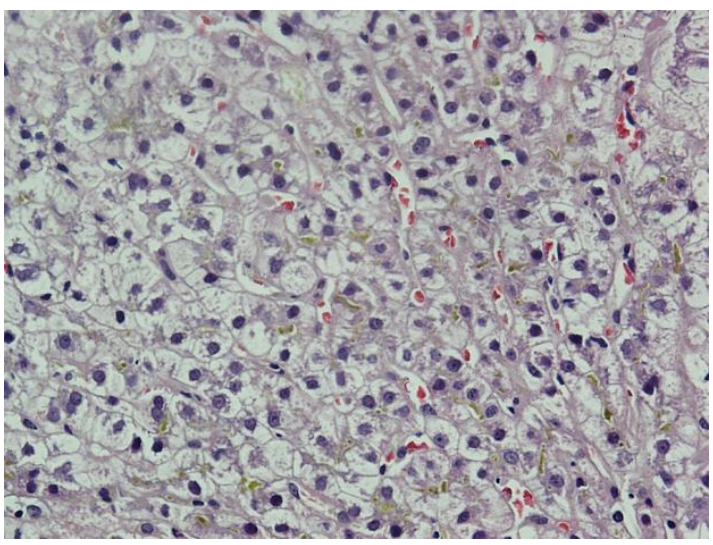

Figure 2. The total bilirubin level changes during the course of the disease

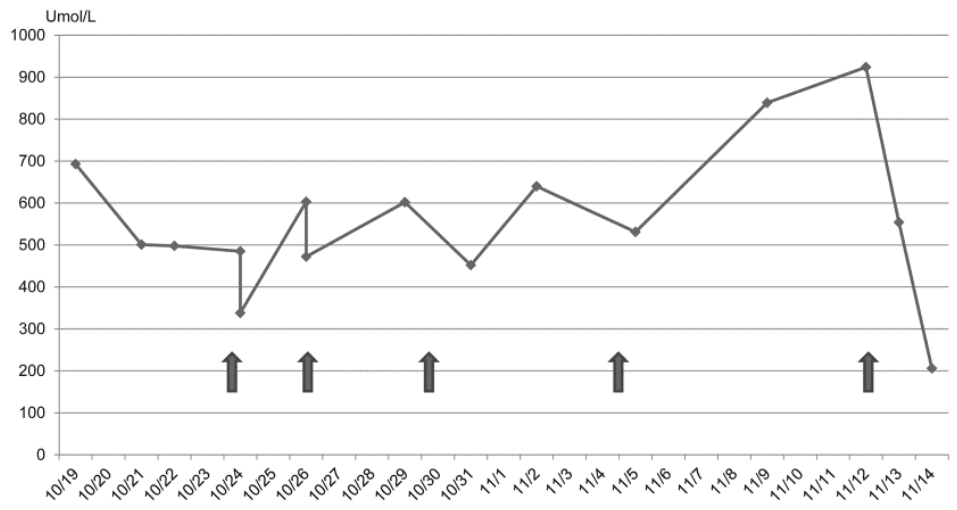

Table 1. Serial liver tests for this patient

\begin{tabular}{|c|c|c|c|c|c|c|}
\hline $\begin{array}{l}\text { Date } \\
\text { Event }\end{array}$ & $\begin{array}{c}\mathbf{1 9 / 1 0} \\
2^{\text {nd }} \text { day } \\
\text { admitted }\end{array}$ & $\begin{array}{c}\mathbf{2 4 / 1 0} \\
{\text { After } 1^{\text {st }}}^{\text {ALS }} \\
\end{array}$ & $26 / 10$ & $\begin{array}{c}\mathbf{2 6 / 1 0} \\
\text { After } 2^{\text {nd }} \\
\text { ALS }\end{array}$ & $29 / 10$ & $\begin{array}{c}\mathbf{3 1 / 1 0} \\
{\text { After } 3^{\text {rd }}}^{\text {ALS }} \\
\end{array}$ \\
\hline Alanine transaminase (normal:5-40 IU/L) & 934 & 192 & 193 & 93 & 119 & 75 \\
\hline Aspartate transaminase (normal:8-40 IU/L) & 1035 & 109 & 201 & 54 & 87 & 68 \\
\hline Bilirubin (Normal:0-21umol/L) & 693 & 338 & 603 & 472 & 602 & 452 \\
\hline Albumin Protein (Normal:35-55g/L) & 34.4 & 31.1 & 29.8 & 32 & 31.3 & 33.1 \\
\hline
\end{tabular}

\begin{tabular}{|c|c|c|c|c|c|c|}
\hline Event & $2 / 11$ & $\begin{array}{c}\mathbf{5 / 1 1} \\
{\text { After } 4^{\text {th }}}^{\text {ALS }}\end{array}$ & 9/11 & $12 / 11$ & $\begin{array}{c}13 / 11 \\
\text { After }^{\text {th }} \\
\text { ALS }\end{array}$ & $\begin{array}{c}\mathbf{1 4 / 1 1} \\
1^{\text {st }} \text { day post } \\
\text { LT }\end{array}$ \\
\hline Alanine transaminase (normal:5-40 IU/L) & 96 & 71 & 143 & 208 & 89 & 101 \\
\hline Aspartate transaminase (normal:8-40 IU/L) & 103 & 64 & 130 & 165 & 75 & 133 \\
\hline Bilirubin (Normal:0-21umol/L) & 640 & 531 & 839 & 924 & 554 & 206 \\
\hline Albumin Protein (Normal:35-55g/L) & 32 & 33.6 & 35.1 & 36.4 & 29.8 & 23.2 \\
\hline
\end{tabular}


After some ordinary medicine treatment, which showed no improvement, he was transferred to the infectious disease department, where the first Artificial Liver Support was performed. After that, the total bilirubin level showed some decline, but increased again on the following test. The second ALS also played a minor role, and the total bilirubin level increased as high as 900 umol/L (Figure 2) and over. So the re-transplantation was considered. And after five times of ALS to buy some time, he was lucky to undergo the operation on the fifth week of the disease.

After undergoing another 3-week post-transplant treatment, the patient recovered and was discharged with normal liver function and a very positive antiHEV IgG marker in his serum, which was still detected at the 3-month follow-up.

\section{Discussion}

Acute hepatitis E virus (HEV) infection is known as a self-limiting symptomatic or asymptomatic disease in people and usually does not need any treatment. It was also observed in immunocompromised individuals, like solid organ transplant recipients and patients with severe hematologic disorders [1,4]. In these patients, about $50 \%-60 \%$ of the cases of acute hepatitis $\mathrm{E}$ infection were reported to have developed into chronic hepatitis with rapid progression to liver cirrhosis $[7,8]$.

HEV is a single-strand, positive-sense RNA, nonenveloped virus with five different genotypes, genotype 1 and 2 infections are restricted to humans, while genotypes 3 and 4 appear to be zoonotic, especially in pigs, and genotype 5 is of avian origin and probably does not infect humans [9]. In China, genotype 1, 3 and 4 were mostly observed, especially genotype 4 , which seemed to become the dominant genotype instead of genotype 1, since 2004 [10].

The diagnosis of HEV infection is based on detection of HEV IgG and/or IgM antibodies in blood serum along with typical clinical symptoms also needs to exclude other types of hepatitis infection. In this case: fatigue, bad appetite and jaundice were the first symptoms, then elevated liver enzymes with significantly increased total bilirubin, both direct and indirect, were observed in the next testing. Finally, anti-HEV $\operatorname{IgG}$ antibody was detected as weaklypositive on the second week of the disease, with antiIgM antibody negative, as well as other hepatitis viruses, so the diagnosis was confirmed.

Artificial Liver Support System (ALSS) has been used as a promising liver assistance system for years and has efficiently decreases the mortality of patients with severe hepatitis in the early and middle stages [11-12], as well as liver cirrhosis and liver failure [1314]. For patients who developed massive necrosis of hepatocytes and lost ability of liver regeneration, several times of ALSS and sequential timely LT were needed [15].

In China, the hepatitis B virus (HBV) infection was very common, and most liver transplantation recipients are HBV related cirrhosis or hepatocellular carcinoma individuals. Thus, in the routine post transplantation check-up, HBV was given careful attention, but hepatitis E virus, as well as hepatitis A virus, which can be infected by oral transmission, are not usually on the list. So we suggest that in some unknown graft, fibrous and abnormal liver function of patients who received liver transplantation, HEV deserves to be considered.

\section{Acknowledgements}

This work was supported by the National High Technology Research and Development Program 863 of China (No. 2012AA021002), and the funding had no role in study design, data collection and analysis, decision to publish, and preparation of the manuscript.

\section{References}

1. Motte A, Roquelaure B, Galambrun C, Bernard F, Zandotti C, Colson P (2012) Hepatitis E in three immunocompromized children in southeastern France. J Clin Virol. 53: 162-166.

2. Halac U, Béland K, Lapierre P, Patey N, Ward P, Brassard J, Houde A, Alvarez F (2012) Chronic hepatitis E infection in children with liver transplantation. Gut 61: 597-603.

3. González Tallón AI, Moreira Vicente V, Mateos Lindemann ML, Achécar Justo LM (2011) Chronic hepatitis E in an immunocompetent patient. Gastroenterología y Hepatología 34: $398-400$.

4. Koning L, Pas SD, de Man RA, Balk AHMM, de Knegt RJ, ten Kate FJ, Osterhaus ADME, van der Eijk AA (2013) Clinical implications of chronic hepatitis $\mathrm{E}$ virus infection in heart transplant recipients. J Heart Lung Transplant. 32: 7885.

5. Schlosser B, Stein A, Neuhaus R, Pahl S, Ramez B, Krüger D H, Hofmann J (2012) Liver transplant from a donor with occult HEV infection induced chronic hepatitis and cirrhosis in the recipient. J Hepatol. 56: 500-502.

6. Tan HH, Leong HN, Tan BH, Oon LLE, Lim KH, Chang JP, Tan CK (2011) Chronic hepatitis e infection resulting in graft failure in a liver transplant tourist. Case reports in transplantation 2011:654792.

7. de Niet A, Zaaijer HL, ten Berge I, Weegink CJ, Reesink HW, Beuers U (2012) Chronic hepatitis E after solid organ transplantation. Neth J Med. 70: 261-266.

8. Kamar N, Selves J, Mansuy JM, Ouezzani L, Péron JM, Guitard J, Rostaing L (2008) Hepatitis E virus and chronic hepatitis in organ-transplant recipients. N Engl J Med. 358: 811-817. 
9. Purcell RH, Emerson SU (2008) Hepatitis E: an emerging awareness of an old disease. Journal Hepatol. 48: 494-503.

10. Zheng Y, Ge S, Zhang J, Guo Q, Ng MH, Wang F, Jiang Q (2006) Swine as a principal reservoir of hepatitis $\mathrm{E}$ virus that infects humans in eastern China. J Infect Dis. 193: 16431649.

11. Santoro A, Mancini E, Buttiglieri S, Krause A, Yakubovich M, Tetta C (2004) Extracorporeal support of liver function (II part). Int J Artif Organs 27: 176-185.

12. Li LJ, Zhang YM, Liu XL, Du WB, Huang JR, Yang Q, Xu XW, Chen YM (2006) Artificial liver support system in China: a review over the last 30 years. Therapeutic apheresis and dialysis: official peer-reviewed journal of the International Society for Apheresis, the Japanese Society for Apheresis, the Japanese Society for Dialysis Therapy 10: 160-167.

13. Nitta M, Hirasawa H, Oda S, Shiga H, Nakanishi K, Matsuda K, Nakamura M, Yokohari K, Hirano T, Hirayama Y, Moriguchi T, Watanabe E (2002) Long-term survivors with artificial liver support in fulminant hepatic failure. Therapeutic apheresis: official journal of the International
Society for Apheresis and the Japanese Society for Apheresis 6: 208-212.

14. Kjaergaard LL, Liu J, Als-Nielsen B, Gluud C (2003) Artificial and bioartificial support systems for acute and acute-on-chronic liver failure: a systematic review. JAMA: the journal of the American Medical Association 289: 217222.

15. Xu X, Liu X, Ling Q, Wei Q, Liu Z, Xu X, Zhou L, Zhang M, Wu J, Huang J, Sheng J, Zheng S, Li L (2013) Artificial liver support system combined with liver transplantation in the treatment of patients with acute-on-chronic liver failure. PloS One 8: e58738.

\section{Corresponding author}

Shusen Zheng,

Division of Hepatobiliary and Pancreatic Surgery, Department of Liver transplantation, First Affiliated Hospital, Zhejiang

University, P.R.China

Tel: 008657187236739

Email: zyzss@zju.edu.cn

Conflict of interests: No conflict of interests is declared. 